\title{
Associations of Self-Determination and Locus of Control with Accepted Level of Automation among Turkish Drivers
}

\author{
Türk Sürücüllerde Ö̈-Belirleyicilik ve Kontrol Odağının Kabul Edilen \\ Otomasyon Seviyesi ile İlişkisi
}

\author{
Pınar BIÇAKSIZ * \\ Selin ŞERMET ** \\ Çağla GíRiş ***
}

\begin{abstract}
The present study investigated Turkish drivers' levels of acceptance of automated driving, along with possible motivational and individual differences, and the antecedents of this acceptance. Specifically, the associations of self-determination theory constructs of the relative autonomy continuum and the general causality orientations (i.e., autonomy, control and impersonal orientations) as the motivational factors for the task of driving with the accepted level of automation were examined. A more intrinsic motivation for driving and autonomy orientation were expected to be negatively related to the accepted level of automation, while extrinsic motivation and an impersonal orientation were expected to be positively related to the acceptance of automation. In addition, the relationship of the general locus of control and the traffic locus of control constructs with the accepted level of automation were investigated, and a positive relationship between an external locus of control and accepted level of automation was expected. The analyses were conducted with a sample of 203 drivers ( $49.8 \%$ women, $51.2 \%$ men) between the ages of 20 and 60 . The results yielded a general trend toward supporting the hypotheses, in addition to low levels of acceptance for this technology, with the strongest association being the positive correlation between the fate dimension of the traffic locus of control and accepted level of automation.
\end{abstract}

Keywords: Automated Driving, Self-Determination Theory, Locus of Control, Turkish Driver Sample

$\ddot{O}_{z}$ : Bu çalışmada Türk sürücülerinin araçtaki otomasyon sistemlerini kabul etme düzeyleri ve bunun olası yordayıcıları olan motivasyon ve bireysel farklılık değişkenleri incelenmiştir. Öz-belirleyicilik kuramı kavramları olan göreli özerklik doğrusu ve genel nedensellik yönelimleri (özerk, kontrol, kişisel olmayan yönelim) ile araçta kabul edilen otomasyon seviyesi arasındaki ilişkiler incelenmiştir. Araç sürmek için daha içsel bir motivasyon ve özerk bir yönelimin kabul edilen otomasyon seviyesiyle olumlu yönlü, dişsal motivasyon ve kişisel olmayan bir yönelimin ise olumsuz yönlü ilişki göstermesi beklenmiştir. Ayrıca genel kontrol odağı ve trafikte kontrol odağı değişkenlerinin araçta kabul edilen otomasyon seviyesi ile ilişkisi incelenmiş ve dışsal kontrol odağının araçta daha yüksek seviyede otomasyonu kabul etme ile olumlu yönlü ilişki göstermesi beklenmiştir. Analizler, yaşları 20 ile 60 arasında değişen 203 (\% 49.8 kadın, \% 51.2 erkek) katılımcı ile yürütülmüştür. Sonuçlar genel olarak hipotezleri destekleyen bir eğilim göstermiştir ve en güçlü ilişki trafikte kontrol odağının kader boyutuyla kabul edilen otomasyon seviyesi arasındaki pozitif korelasyon bulgusudur.

Anahtar sözcükler: Sürücü Otomasyon Sistemleri, Öz-Belirleyicilik Kuramı, Kontrol Odağı, Türk Sürücü Örneklemi

\footnotetext{
* Dr. Öğr. Üyesi, Hacettepe Üniversitesi, Edebiyat Fakültesi, Psikoloji Bölümü, Ankara. pbicaksiz@gmail.com, https://orcid.org/0000-0002-8376-6145

** Psikolog, Ankara. sermetselin@yandex.com, https://orcid.org/0000-0001-6285-590X

*** Psikolog, Ankara. caglagiris@ gmail.com, https://orcid.org/0000-0002-2742-9590
} 
Road traffic crashes are the ninth leading cause of global death (World Health Organization; WHO 2014), and are estimated to become the fifth leading cause of death by 2030 (WHO 2008). Since, the human operator's behavior is a significant factor in road safety (Petridou \& Moustaki 2000), vehicles without a human operator, or so called self-driving, driverless or autonomous cars, are expected to contribute to the solution of this serious problem (Hulse, Xie \& Galea 2018).

Not surprisingly, automated driving, which correspond to the fifth and highest level of automation (Society of Automotive Engineers International SAE 2014), is expected to become a widely used mode of transportation in the future (Bazilinskyy et al. 2015). SAE (2014) defines this level as "full automation" and it involves the performance of the operational and tactical aspects of the driving task being performed by the automated driving system for the total travel time in every environmental and road condition that can be handled by a human operator. However, the strategic aspect of the driving task such as determination of the destination and the waypoints are still carried out by the human operator.

Although automated driving is a much debated topic in academia, government and industry, there is still limited scientific knowledge with respect to the level of acceptance of this technology (Bazilinskyy et al. 2015). The aim of the present study is to investigate the levels of automation of a car that are accepted by Turkish drivers and whether locus of control and selfdetermination motivation are linked to the accepted level of automation.

\section{Self-Determination Theory and General Causality Orientations}

Self-determination theory (SDT) differs from other motivation theories by focusing on different types of motivation based upon levels of autonomy, instead of the quantity of motivation (Deci \& Ryan 2000). The concept of autonomy is crucial to understanding the quality of behavioral regulation and SDT attempts to understand how autonomy develops, how it can be supported or hindered by specific social and biological conditions as well as the nature and consequences of it (Ryan \& Deci 2006).

In SDT, autonomy for a specific action is a matter of degree and the relative autonomy continuum is presented depicting intrinsic motivation at the most autonomous end and four types of extrinsic motivation having varying degrees of internalization (Ryan \& Deci 2000). Internalization is a natural and active process in which the transformation of socially sanctioned requests or mores into personally affirmed values and self-regulations is attempted (Ryan, Connell \& Deci 1985). In this relative autonomy continuum, the most controlled form of motivation is external regulation that involves alienated behavior and it is the type of motivation examined by operant theorists. The second, relatively more internalized form of extrinsic motivation is introjected regulation that entails taking in a regulation but not completely accepting it as one's own, that is performing an act to avoid internal punishments (such as guilt or anxiety) or to attain internal rewards (such as pride). The third form of extrinsic motivation is identified regulation in which the action is accepted as personally important and the behavioral goal is consciously valued. The fourth, and most autonomous form of extrinsic motivation is integrated regulation in which the regulations are fully assimilated to the self by bringing them into congruence with the person's other values and needs. These have many common qualities with intrinsic motivation but are still considered as being extrinsic motivation because they are performed to obtain separable outcomes instead of the inherent enjoyment of the activity; since what distinguishes intrinsic versus extrinsic motivation is that the former involves displaying acting out a behavior for its inherent satisfaction, whereas the latter involves doing something to obtain a separable goal (Deci \& Ryan 1987). In the current study, a negative relationship between individuals' position on this relative autonomy continuum and their accepted levels of autonomy in their cars is expected. It is expected that as individuals stand toward the intrinsic end of this continuum, they would be less likely to accept higher levels of 
automation in their cars. That is, if a genuine intrinsic motivation for driving entails carrying out the driving task just for the joy of it, then these individuals would not be willing to give up this joy by leaving the driving task to the automated system.

Deci (1980) suggested the term "causality orientations" to refer to individual differences regarding motivational orientations toward the regulation and initiation of behavior. He argued that there are three such orientations, namely autonomy, control, and impersonal. Individuals with a high autonomy orientation are more likely to be intrinsically motivated and less likely to be controlled by extrinsic rewards. On the other hand, individuals having a high control orientation are more likely to be regulated by environmental or personal controls, that is, extrinsic rewards determine their behavior to a greater degree. Finally, individuals with a high impersonal orientation believe that forces rather than personal intention initiate and regulate behavior. In the present study, it is expected that individuals with a high impersonal orientation will be relatively more willing to rely on the automated system since they perceive tasks as being too difficult and have a sense of incompetence (Deci \& Ryan 1985). As for autonomy orientation, a negative association with accepted level of automation is expected. Individuals with high autonomy orientation search for opportunities for choice and self-determination (Deci \& Ryan 1985), therefore they would be less willing to let the automated driving system be in charge of the driving task instead of themselves. With regard to control orientation, no specific hypotheses are formulated, but a pattern of associations closer to those of autonomy orientation than the impersonal orientation can be expected, since, although extrinsic, there still is motivation and regulation in control orientation, as opposed to the case for impersonal orientation.

\section{Locus of Control}

The term locus of control was first coined by Rotter (1966) and refers to the expectancy of individuals for external versus internal control of reinforcement. That is, people who believe that their own behaviors determine their rewards are suggested as having an internal locus of control, while those believing that factors other than their own behavior determine their rewards and therefore they do not have any control over their rewards are suggested as having an external locus of control. According to Rotter (1966), individuals perceive rewards as being contingent or noncontingent upon their behaviors, and generalize this perception. Then, throughout their developmental process, individuals might develop general expectations about rewards being either controlled by themselves or by forces other than themselves. The former is conceptualized as believing in an internal locus of control, whereas the latter as believing in an external locus of control. However, based upon the nature of reinforcement experiences throughout the developmental process a significant polarization might not have taken place and the individual might stand somewhere in the middle on this continuum.

Locus of control has been studied in the driving context, but the findings have been mixed. In one study, the internal locus of control was related to cautious driving and taking precautionary actions, while the external locus of control was linked to fatal crash involvement (Montag \& Comrey 1987). However, another study reported the opposite pattern of associations (Arthur \& Doverspike 1992). Yet another study found no direct link between Rotter's locus of control and crash involvement (Guastello \& Guastello 1986). A relevant finding in the literature examining the locus of control in the driving context is that car travel is a more interesting and involving experience for those drivers with an internal locus of control (Hoyt 1973). That is, since they experience driving a car as being more interesting and involving, it can be expected that drivers with an internal locus of control would have a lower tendency to accept full automation in their cars. In addition, Rudin-Brown and Parker (2004) reported supporting evidence for their propositions that drivers with an internal locus of control prefer to keep more 
direct involvement with the driving task instead of using in-vehicle intelligent transportation systems, whereas those with an external locus of control had a greater tendency to rely on these systems. This finding also supports the present study hypothesis that the internal locus of control is linked to a lower level of automation accepted in a car, which is the same as expecting that the external locus of control is associated with a higher level of automation accepted in a car, since the scale used to measure locus of control in the current study is a unidimensional one - treating the internal and the external locus of control as at the ends of a continuum.

Researchers also developed domain specific measures of locus of control with the rationale that to arrive at the most accurate results, instruments that tailor the construct to the specific domain or behavior should be used instead of general measures (Rotter 1975; Phares 1976; Lefcourt 1982; 1991); such as academic locus of control (Trice 1985); health locus of control (Wallston et al. 1976); marital locus of control (Miller, Lefcourt \& Ware 1983); and work locus of control (Spector 1988). In a similar vein, Özkan and Lajunen (2005) developed the traffic locus of control scale to measure drivers' attributions about the causes of road traffic crash involvement. This multidimensional scale consists of four dimensions, namely self, vehicle and environment, fate, and other drivers. In the present study, it is expected that, drivers who display a higher level of self locus of control in traffic would accept a lower level of automation in their cars. That is, it can be postulated that drivers who have a greater tendency to attribute the causes of road traffic crashes to their own behavior rather than to other factors such as the vehicle and environment or to other drivers, have a feeling of being in charge while driving and therefore would be less likely to accept that an automated system be in full control of the driving task when they are available to do that. On the other hand, drivers having a greater tendency to attribute the causes of accidents to external factors, namely vehicle and environment, fate, or other drivers, are expected to accept a higher levels of automation in their cars, since they have a rather less sense of being in charge compared to those high in the self dimension of the traffic locus of control. Therefore, it is expected that the vehicle and environment, other drivers, and fate dimensions would yield positive associations with the accepted level of automation, whereas a negative relationship is expected between the self dimension of the traffic locus of control and the accepted level of automation.

\section{Method}

\section{Participants and Procedure}

To reach "drivers" to fill out the online questionnaire package, the convenience sampling with snowball technique was used. The study was announced on social media using many different accounts of people who volunteered to help distribute the survey. The link to the online version of the questionnaire package was also posted to these social media websites. The eligibility criteria were to hold a valid driver's license and have driven at least $3000 \mathrm{~km}$. A total of 203 drivers (49.8\% Women, 50.2 \% Men), between the ages of 20 and $60(M=28.94, S D=11.11)$ filled out the questionnaire package. The average total mileage was $99039 \mathrm{~km}$ (SD = 228380.65 ) with a range of $3000-2000000 \mathrm{~km}$.

\section{Instruments}

Demographic information form: In this section of the survey, participants were asked to indicate their age, gender and total mileage in kms.

Accepted Level of Automation: The accepted level of automation in a car was measured by one multiple-choice question with an instruction to choose which of the options the participants think that they can accept in a car they are operating, and with response options being the definitions of SAE levels from 0 (no automation) to 5 (full automation). The response options for this question are as follows: 
$0=$ no automation; the human drivers himself/herself performs all aspects of the driving task

$1=$ driver assistance; the system may support the human driver in terms of steering and speed choice, but still the human operator is responsible for the whole driving task

2 = partial automation; the system may control steering and speed functions under certain conditions, but still the human operator is responsible for the whole driving task

3 = conditional automation; the system controls steering and speed functions and monitors the environment through sensors, but the human drivers should be readily available to intervene when necessary

4 = high automation; the system controls every aspect of the driving task and requests intervention from the human driver, continues to operate the vehicle if the human driver does not respond to the intervention request

$5=$ full automation; the system controls all aspects of the driving task and carries out all of the functions that the human operator is capable of during the whole drive.

Self-Determination Motivation: First, the degree to which the motivation for the driving task is self-determined was measured by one multiple-choice question. The response options reflect the definitions of the forms of motivation on the relative autonomy continuum (Ryan \& Deci 2000) adapted for the driving task context. The response options were as follows:

1 (amotivation) $=\mathrm{I}$ have no motivation for driving a car.

2 (external regulation $)=$ Driving a car is just a method of transportation for me .

3 (introjected regulation) $=$ Driving is a source of pride and self-confidence for me.

4 (identified regulation) $=$ Driving is an important value for me and I am responsible for all of my actions while driving.

5 (integrated regulation) $=$ Driving is one of the important aspects of my self construct and supports my goals in other domains of life.

6 (intrinsic motivation) $=\mathrm{I}$ drive just for the joy of driving a car.

General Causality Orientations: The scale was developed by Deci and Ryan (1985) and adapted to Turkish by Şen and Dağ (2016). The scale has three subscales, namely the autonomy orientation, control orientation and the impersonal orientation. The scale is composed of 17 short vignettes and three items for each vignette, for which the participants are instructed to rate the extent to which the behavior/thought/feeling would be characteristic of them in that situation. The items required responding on a 7-point scale ranging from 1 (would never be a characteristic of me) to 7 (would totally be a characteristic of me). The higher scores obtained on the subscales reflected higher levels of the given orientation. In the current study, the Cronbach's Alpha coefficients for the subscales were respectively: .89 for autonomy; .61 for control; and .73 for impersonal orientations.

Locus of Control: Dağ (2002) developed this 47-item scale and reported a Cronbach's Alpha value of .92 for the total scale and a test-re-test reliability coefficient of $r=.88$. The items required responses on a 5-point scale ranging from 1 (strongly disagree) to 5 (strongly agree) and the higher scores obtained on this scale showed higher levels of an external locus of control. The Cronbach's Alpha coefficient for the total scale was .87 in the present study.

Traffic Locus of Control (T-LOC): Özkan and Lajunen (2005) developed the 17-item scale. The scale consists of four dimensions reflecting the sources that drivers attribute the causes of traffic accidents. The items required responding on a 5-point scale, ranging from 1 (not at all possible) to 5 (highly possible), and the higher scores obtained on each dimension reflect higher levels of the given dimension. The Cronbach's Alpha coefficients for the subscales in the present study were: .77 for self; .76 for other drivers; .62 for vehicle and environment; and .59 for fate. 


\section{Results}

\section{Descriptive Analyses}

Participants were asked to indicate which level of autonomy they would accept in their cars among the six options ranging from no automation to full automation. It was found that $38,4 \%(\mathrm{~N}$ $=78$ ) of the participants chose the "no automation" option as the most applicable one among the alternatives, and $29,6 \%(N=60)$ chose the "driver assistance" option, which corresponds to the least automated system. On the other hand, only 3,9\% $(N=8)$ reported accepting the "full automation" and $3 \%(N=6)$ indicated the "high automation" options. Therefore, it can be stated that the sample of the current study has a low level of acceptance of automation in their cars.

The age of the participants yielded a positively skewed distribution with a skewness value of 1.34 , and $73,3 \%$ of participants being between ages 20 and 30. This shows that the sample of the current study is a relatively young sample. In line with this finding, the total mileage values were also positively skewed (with a skewness value of 6.173), since age and total mileage are significantly positively related $(r=.32, p<.001)$. Therefore, the study sample can be regarded as a young driver sample.

\section{Correlations between the study variables}

The bivariate Pearson correlation coefficients between the study variables are presented in Table 1. Among the demographic variables used in the current study, only age yielded a marginally significant correlation with the accepted level of automation $(r=-.13, p=.063)$. That is, as drivers get older, they tended to accept a lower level of automation in their cars. However, gender and total mileage did not yield significant correlations with the accepted level of automation.

Second, the nature of the motivation regarding the driving task, from amotivation to intrinsic motivation, was not significantly correlated with the accepted level of automation. With regard to the general causality orientations, autonomy orientation was negatively associated with the accepted level of automation $(r=-.15, p=.060)$ as expected, while the control and impersonal orientations yielded negative but nonsignificant correlations with the accepted level of automation in the car.

Third, the association of the general locus of control with the accepted level of automation was examined. It was found that the locus of control was marginally positively related to the accepted level of automation $(r=.14, p=.060)$. That is, since higher values on the locus of control variable reflected the external locus of control, this result indicated that the external locus of control was associated with higher levels of automation accepted in the car, as was expected.

Finally, the correlations of the traffic locus of control dimensions with the accepted level of automation were investigated. Among the four dimensions, only fate was found to be significantly associated with the accepted level of automation in the car $(r=.15, p<.05)$. As expected, as drivers' tendency to attribute the causes of accidents to fate increases, they tended to accept higher levels of automation in their cars.

\section{Regression Analyses}

A series of hierarchical regression analyses were conducted to examine the associations between each set of predictors with the accepted level of autonomy after controlling for age, gender and total mileage. A multiple regression model enables controlling for the relationships among predictors and therefore the amount of unique variance in the DV explained by each predictor can be observed. The results of these separate analyses for each set of predictors (namely general causality orientations, locus of control, and dimensions of traffic locus of control) can be seen in Table 2 . 


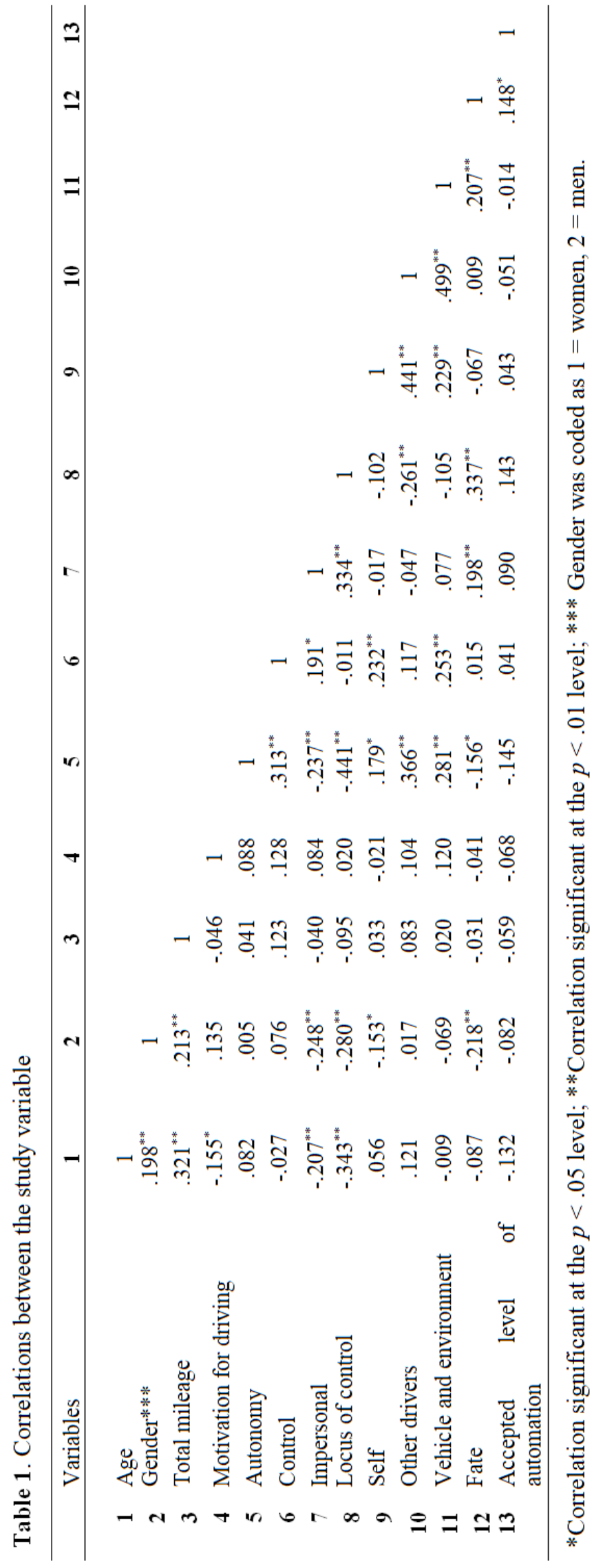


Table 2. Combined results of the separate hierarchical regression analyses

\begin{tabular}{|c|c|c|c|c|}
\hline & \multicolumn{4}{|c|}{ DV: Accepted Level of Automation } \\
\hline & $R^{2}$ & $R_{\text {change }}^{2}$ & Beta & $p$ \\
\hline Step 1 (Control Variables) & .02 & .02 & & .328 \\
\hline Age & & & -.12 & .136 \\
\hline Gender & & & -.06 & .459 \\
\hline Total mileage & & & -.01 & .914 \\
\hline Step 2 (General Causality Orientations) & .05 & .03 & & .217 \\
\hline Autonomy orientation & & & -.17 & .052 \\
\hline Control orientation & & & .10 & .250 \\
\hline Impersonal orientation & & & -.01 & .944 \\
\hline Step 2 (Locus of Control) & .03 & .01 & & .204 \\
\hline Locus of control & & & .10 & .204 \\
\hline Step 2 (Traffic Locus of Control) & .05 & .03 & & .295 \\
\hline Self & & & .09 & .256 \\
\hline Other drivers & & & -.06 & .516 \\
\hline $\begin{array}{r}\text { Vehicle and environment } \\
\text { Fate }\end{array}$ & & & $\begin{array}{l}-.04 \\
.15\end{array}$ & $\begin{array}{l}.653 \\
.049^{*}\end{array}$ \\
\hline
\end{tabular}

*Significant at $p<.05$ level

In the first analysis, the predictors were the dimensions of the general causality orientations, namely autonomy, control and impersonal orientations. After controlling for age, gender and total mileage in the first step, the three predictors explained $5 \%$ variance in the accepted level of automation $\left(R^{2}=.05, R_{\text {change }}^{2}=.03, n s\right)$. While the associations of control and impersonal orientations were not significant, autonomy orientation yielded a marginally significant negative relationship with the accepted level of automation $(\beta=-.17, p=.052)$. In line with expectation, as the participants' autonomy orientation increased, their accepted level of automation in their cars decreased.

The second analysis was carried out using the locus of control as the predictor, but it did not yield a significant association with the accepted automation level, after controlling for age, gender and total mileage.

Finally, self, other drivers, vehicle and environment, and fate dimensions of the traffic locus of control measure were entered in the second step as predictors after age, gender and total mileage was controlled in the first step. The three predictors explained $5 \%$ variance in the accepted level of automation $\left(R^{2}=.05, R_{\text {change }}^{2}=.03, n s\right)$. Only the fate dimension yielded a significant positive relationship with the accepted level of automation $(\beta=.15, p<.05)$. That is, as participants' tendency to attribute the causes of accidents to fate increased, they tended to accept a higher level of automation in their cars.

\section{Discussion}

The current study investigated the drivers' accepted level of automation in their private cars, along with the potential individual difference related antecedents of this acceptance. To the best of our knowledge, this is the first study examining the degree of acceptance for self-driving cars amongst Turkish drivers. In addition, to the best of the authors' knowledge, this is also the first 
study in the literature that examines the locus of control and self-determination motivation in the realm of acceptance of automated systems. Results yielded a general trend toward supporting the expected associations.

With regard to the analyses findings testing the expected associations, firstly, although the nature of the motivation for the driving task was not significantly related to the accepted level of autonomy, the directions of associations of the general causality orientations dimensions were found to be in line with expectations. That is, while the autonomy orientation was negatively related to the accepted level of automation, impersonal orientation was found to be positively related. As individuals with a high autonomy orientation would tend to prefer self-determination and own initiation in the driving task, they were expected to accept lower levels of automation in their cars and this expectation was supported with a marginally significant negative correlation. In addition, it was expected that individuals with higher levels of impersonal orientation would be more willing to yield control of the driving task to the automated system since they believe in the role of external forces in the initiation and regulation of behavior rather than their own intentions (Deci \& Ryan 1985). A positive but nonsignificant association between impersonal orientation and the accepted level of automation showed a trend toward supporting this expectation.

Secondly, the external locus of control was expected to be positively related to the accepted level of automation. As expected, the locus of control yielded a positive marginally significant correlation in line with this expectation. As expected, individuals with a higher external locus of control reported accepting higher levels of automation in their cars. This finding is compatible with previous research indicating that drivers with an external locus of control tend to rely upon in-vehicle intelligent technologies (Rudin-Brown \& Parker 2004). In addition, this finding can be explained by the belief characterizing the external locus of control that the outcome of behaviors are controlled by factors other than own behaviors (Rotter 1966). Therefore, with this sense of lack of control, drivers with the external locus of control would be more willing to let the automated system control the operation of their cars instead of themselves.

Thirdly, with regard to the traffic context specific locus of the control dimensions, it was expected that the self dimension would be negatively, and the other three dimensions, namely other drivers, vehicle and environment, and fate, would be positively associated with the accepted level of automation. Among these dimensions, only fate yielded a significant relationship with the accepted level of automation in the expected direction. That is, individuals with a greater tendency to attribute the causes of traffic accidents to fate reported higher levels of acceptance of automation in their cars. Since drivers with a higher belief in fate as a cause of traffic accidents would assume less responsibility for their own actions while driving, and would perceive the personal control and involvement with the driving task and the driving environment as less important, they would be more willing to yield the control of the vehicle to the automation system.

Finally, in the exploratory descriptive analyses, it was found that most of the participant drivers reported acceptance of lower levels of automation in their cars. In other words, it can be stated that the level of acceptance for automated driving systems of the current sample is relatively low. Overall, this result is in line with previous studies. For instance, a "large hesitation toward autonomous vehicle adoption" has been documented in Israel (Haboucha, Ishaq \& Shiftan 2017, 37). In another study with 5000 respondents from 109 different countries, manual driving was found to be the most enjoyable and automated driving would be the least enjoyable mode of driving (Kyriakidis, Happee \& de Winter 2015). In the case of Turkey, the reason for the low level of acceptance might be lower levels of public knowledge on the issue of driverless cars and their advantages. In addition, the transition to a system composed of fully 
automated cars and a traffic system in our country, which is a developing country, might be perceived by the Turkish public as a reality of a far distant future, as opposed to the case in industrialized countries. However, these are only possible reasons, none of which has been measured in the present study. Therefore, future studies might investigate the reasons of the relatively low acceptance of automated cars among Turkish drivers.

All in all, the study findings generally yielded results in the expected direction although some of the associations turning out to be nonsignificant. However, the limitations of the current study, especially pertaining to the sample size and the predominantly young age limits the generalizability of the findings. Therefore, it can be suggested that future studies that aim to examine the acceptance of automated driving systems technology among Turkish drivers should try to reach a more diverse sample in terms of age, and therefore driving experience, since the two are correlated. In addition, the measurement of the accepted level of automation might be regarded as a limitation of the present study. That is, the participants were asked to choose the automation level that they find most acceptable among the definitions of the levels of automation, and their choices in this question was used as the dependent variable in all the analysis. However, a scale composed of multiple questions might be developed to achieve a more reliable measurement of the variable at hand. Therefore, developing a scale to measure attitudes toward autonomous vehicles, and examining the associations of the individual difference variables used in the current study with this newly developed measure might provide important insights toward understanding the phenomenon of acceptance and attitudes toward autonomous cars in Turkey. This study, in a way, may be considered a preliminary effort and a forerunner for an emerging fruitful field of research in our country.

\section{Author's Note:}

Analysis results with a portion of the data and some of the variables used in the present study were orally presented at an international conference. 


\section{REFERENCES}

Arthur W. \& Doverspike D. (1992). "Locus of Control and Auditory Selective Attention as Predictors of Driving Accident Involvement: A Comparative Longitudinal Investigation". Journal of Safety Research 23 (1992) 73-80.

Bazilinskyy P., Kyriakidis M. \& de Winter J. (2015). “An International Crowdsourcing Study into People’s Statements on Fully Automated Driving”. Procedia Manufacturing 3 (2015) 2534-2542.

Dağ İ. (2002). "Kontrol Odağı Ölçeği (KOÖ): Ölçek Geliştirme, Güvenirlik ve Geçerlik Çalışması”. Türk Psikoloji Dergisi 17 (2002) 77-90.

Deci E. L. \& Ryan R. M. (1985). “The General Causality Orientations Scale: Self-determination in Personality". Journal of Research in Personality 19 (1985) 109-134.

Deci E. L. \& Ryan R. M. (1987). "The Support of Autonomy and the Control of Behavior". Journal of Personality and Social Psychology 53 (1987) 1024-1037.

Deci E. L. \& Ryan R. M. (2000). "The "what" and "why" of Goal Pursuits: Human Needs and the Selfdetermination of Behavior”. Psychological Inquiry 11 (2000) 227-268.

Deci E. L. (1980). The Psychology of Self-determination. Lexington 1980.

Guastello S. J. \& Guastello D. D. (1986). "The Relation Between Locus of Construct and Involvement in Traffic Accidents". The Journal of Psychology 120 (1986) 293-297.

Haboucha C. J., Ishaq R. \& Shiftan Y. (2017). "User Preferences Regarding Autonomous Vehicles". Transportation Research Part C 78 (2017) 37-49.

Hoyt M. F. (1973). "Internal-External Control and Beliefs about Automobile Travel”. Journal of Research in Personality 7 (1973) 288-293

Hulse L. M., Xie H. \& Galea E. R. (2018). "Perceptions of Autonomous Vehicles: Relationships with Road Users, Risk, Gender and Age”. Safety Science 102 (2018) 1-13. Doi: http://dx.doi.org/10.1016/ j.ssci.2017.10.001

Kyriakidis M., Happee R. \& de Winter J. C. F. (2015). "Public Opinion on Automated Driving: Results of an International Questionnaire Among 5000 Respondents". Transportation Research Part F 32 (2015) 127-140.

Lefcourt H. M. (1982). Locus of Control. Current Trends in Theory and Research. Hillsdale 1982.

Lefcourt H. M. (1991). Locus of Control. Eds. J. P. Robinson, P. R. Shaver \& L. S. Wrightsman, Measures of Personality and Social Psychological Attitudes (1991) 413-499. San Diego.

Miller P. C., Lefcourt H. M. \& Ware E. E. (1983). "The Construction and Development of the Miller Marital Locus of Control Scale”. Canadian Journal of Behavioral Science 15 (1983) 266-279.

Montag I. \& Comrey A. L. (1987). "Internality and Externality as Correlates of Involvement in Fatal Driving Accidents". Journal of Applied Psychology 72 (1987) 339-343.

Özkan T. \& Lajunen T. (2005). "Multidimensional Traffic Locus of Control Scale (T-LOC): Factor Structure and Relationship to Risky Driving". Personality and Individual Differences 38 (2005) 533-545.

Petridou E. \& Moustaki M. (2000). "Human Factors in the Causation of Road Traffic Crashes". European Journal of Epidemiology 16 (2000) 819-826.

Phares E. J. (1976). Locus of Control in Personality. Morristown 1976.

Rotter J. B. (1966). "Generalized Expectancies for Internal vs. External Control of Reinforcement". Psychological Monographs 80 (1966) 1-28.

Rotter J. B. (1975). "Some Problems and Misconceptions Related to the Construct of Internal Versus External Control of Reinforcement”. Journal of Consulting and Clinical Psychology 43 (1975) 56-67.

Rudin-Brown C. M. \& Parker H. A. (2004). "Behavioural Adaptation to Adaptive Cruise Control (ACC): Implications for Preventive Strategies". Transportation Research Part F: Traffic Psychology and Behaviour 7 (2004) 59-76.

Ryan R. M. \& Deci E. L. (2000). "Self-Determination Theory and the Facilitation of Intrinsic Motivation, Social Development, and Well-Being”. American Psychologist 55 (2000) 68-78.

Ryan R. M. \& Deci E. L. (2006). "Self-Regulation and the Problem of Human Autonomy: Does Psychology Need Choice, Self-Determination, and Will?” Journal of Personality 74 (2006) 1557-1585.

Ryan R. M., Connell J. P. \& Deci E. L. (1985). "A Motivational Analysis of Self-Determination and SelfRegulation in Education”. Eds. C. Ames \& R. E. Ames, Research on Motivation in Education: The Classroom Milieu (1985) 13-51. New York. 
Şen G. \& Dağ İ. (2016). “Genel Nedensellik Yönelimleri Ölçeğinin Türkçeye Uyarlanması, Geçerlilik ve Güvenilirliğinin Üniversite Öğrencilerinde Sınanması”. Anadolu Psikiyatri Dergisi 17 (2016) 100-107.

Society of Automotive Engineers (SAE) International (2014). Standard J3016: Taxonomy and Definitions for Terms Related to On-Road Motor Vehicle Automated Driving Systems. Retrieved from http://www.sae.org/misc/pdfs/automated_driving.pdf

Spector P. E. (1988). "Development of the Work Locus of Control Scale". Journal of Occupational Psychology 61 (1988) 335-340.

Trice A. D. (1985). "An Academic Locus of Control Scale for College Students". Perceptual and Motor Skills 61 (1985) 1043-1046.

Wallston B. S., Wallston K. A., Kaplan G. D. \& Maides S. A. (1976). "Development and Validation of the Health Locus of Control (HLC) Scale”. Journal of Consulting and Clinical Psychology 44 (1976) 580585.

World Health Organization (2008). World health statistics 2008. Retrieved from: www.who.int/whosis/ whostat/2008/en/index.html

Word Health Organization (2014) The 10 Leading Causes of Death in the World, 2000 and 2012. Retrieved from; http://www.who.int/mediacentre/factsheets/fs310/en 